'A BETTER LIFE FOR ALL':

\title{
A REALITY OR A PIPE-DREAM? A BLACK THEOLOGY INTERVENTION IN CONDITIONS OF POOR SERVICE DELIVERY IN THE DEMOCRATIC SOUTH AFRICA
}

\author{
MJ Manala \\ Practical Theology \\ University of South Africa
}

\begin{abstract}
South Africans have recently witnessed a string of protests against poor service delivery on the part of government departments, especially municipalities, in spite of the promised 'better life for all.' This article asks critical questions: how long are black South Africans still to wait for the promised 'better life for all'? Is the promised 'better life for all' just one of empty slogans used to keep the black majority hoping against hope? The article examines the recent protests against poor service delivery. It also decries the abject poverty, unemployment, homelessness, impoverishment and hopelessness that black South Africans continue to experience contrary to their raised expectations for 'a better life for all.' The article appeals for the intervention of Black Theology which seems to have been silenced since the coming to power of the democratic government in 1994. The government must be challenged to deliver services and stamp out corruption.
\end{abstract}

Key Words: A better Life for All, Service Delivery Protests, Unemployment, Black Theology, Greed and Corruption

\section{Introduction}

In their Research Report 100, Gardner Khumalo, Libhongo Ntlokonkulu \& Thabo Rapoo point to the severe lack of capacity at municipal level that leads to lack of or poor service delivery. They also point to severe lack of funds that hinders efficient and effective fulfilment of their mandate of improving the quantity and quality of basic services to citizens. Poor service delivery in South African townships and villages whatever its causes, delays the realisation of the 1994 promised 'better life for all.' This delay perpetuates the continued dehumanisation and impoverishment that the black masses have had to endure since the arrival on our shores of White people who annexed and colonised every corner of our people's land and lives, leaving them in abject poverty. The black citizens are indeed the ones who have to struggle with lack of basic services in their townships and informal settlements. This is aptly expressed by Puleng LenkaBula (2005:104) in a different context: "The plight of those who were deprived of their humanity and livelihoods by apartheid has not fundamentally changed." They rightly therefore continue to feel neglected. The irony is that the present neglect comes from the structures of the people's government that came to power in 1994 promising citizens 'a better life for all.' This fact makes it the more painful to the black citizens who had fought so hard for their liberation and betterment of their lives. Instead they continue to experience the ravaging effects of poor service delivery which exacerbates poverty contrary to recent election promises by the newly elected administration under president Zuma's leadership - of improved service delivery. Persistent poor service delivery has inexorably led to the eruption of violent protests in recent weeks. 
The Mail and Guardian (http://www.mg.co.za/-section/national 20 July 2009) reports that in the four recent weeks disgruntled people have taken to the streets in twenty towns, according to police reports.

This article highlights poor service delivery at local government level and the consequent residents' protests against lack of or poor service delivery. It further points to greed and corruption of some local government employees as one of disabling factors to basic service delivery. The questions: how long are black South Africans still to wait for the promised 'better life for all?'; is the promised 'better life for all' just one of empty slogans used to keep the black majority hoping against hope?; and trying to make sense of the fierce protests spearheaded by the black masses. These questions are meant to probe the commitment of the government and government officials to service delivery.

\section{Poor Service Delivery}

Leaders are elected and government officials appointed to provide services to God's people. Jesus of Nazareth described his leadership in the words that highlight service and selfgiving as the central motif of his ministry (Mk 10:45; Mt 20:28). With Jesus, altruism is the core of involvement in human salvation and development. Jesus gave his disciples the instruction to serve and to not expect to be served. The problem that impedes or delays service delivery in our villages and townships is to my mind lack of commitment to serving others and the seeming exaggerated desire for self aggrandisement. It seems probable to search for reasons for this situation in the legacy of apartheid as LenkaBula (2005:104) notes: "Not only did apartheid's reign pervert morality and dehumanise the majority of South African citizens, it also damaged the moral fibre and integrity of the entire nation." The values of serviceability and self-giving seem to have been eroded by the apartheid opium.

There have as a result, recently been fierce service delivery protests by residents characterised by the barricading of streets with burning tyres and huge rocks, the burning down of state properties, injury and serious threat to human life. In one incident the councillor of Mamelo in Sedibeng Municipality was reportedly briefly taken hostage by protesters demanding better service delivery. People suspect, understandably that politicians are only interested in their votes after which they care less whether they get the promised services or not - people are enraged by the thought of being used as pawns in political power games. This is clear from the words of a fifty seven year old woman, recorded on page 4 of the Daily Sun of Thursday $05^{\text {th }}$ January 2010: "We are sick and tired of being taken advantage of, especially when it is election time. We are not going to stop the protests until 14 January when council offices open." One cannot do otherwise, but sympathise with the poor to whom promises are made but rarely kept. In this incident residents were protesting against lack of electricity, tarred roads, tap water, clinics and hospitals. These are indeed basic needs without which life is extremely difficult especially for people whose hopes were ignited and expectations raised by the coming to power of the democratic government in 1994.

Lack of service delivery is rife also in the area of building and delivery of RDP houses to the poor. The problem here is threefold. Firstly, there is shoddy workmanship. It is for instance reported that 3000 houses in the Northern and Eastern Cape would have to be destroyed because of shoddy workmanship (http://www.theherald.co.za 2009/11/02). The demolition of those houses meant that they would have to be replaced at a high cost. Secondly, incomplete projects while funds have been depleted. Some unscrupulous business people who won building tenders for RDP houses are said to have left projects at 
foundation level disappearing with money amounting to millions of Rands meant to build shelter for the poor. Such incidents have been reported to be widespread in Limpopo, but also in other provinces. Thirdly, the selling of RDP houses by corrupt government officials charged with the responsibility of allocating these houses to the poor for free. E-tv's $3^{\text {rd }}$ degree programme and the Sowetan newspaper have uncovered a scam in which the poor are exploited. The dodgy operators offer to supply a RDP house for R6000 promising to hand keys and title deeds within weeks. The scam was shown on E-tv's $3^{\text {rd }}$ degree on Tuesday 2009/07/07 at 21:30.

\section{Service Delivery Protests}

I do not intend here, to cover all protests over poor or lack of service delivery. I will only highlight a few protests which will hopefully give a clearer picture of the situation facing South Africans fifteen years into democracy. Some of the protests are indeed reminiscent of the apartheid era protests. They are at times quite violent and destructive of the country's most valued properties such as the burning down of the state library in Siyathemba.

Most of the service delivery protests between January and July 2009 occurred in Gauteng namely, 30\%, followed by $17 \%$ in Northwest and $15 \%$ in the Free State (News24.com). The Mail and Guardian (http://www.mg.co.za/-section/national July, 26 2009) reports that twenty four major protests had erupted mainly in Gauteng, Mpumalanga and Western Cape. The year 2009 was indeed characterised by many service delivery protests. Peter Alexander's (2010:28) preliminary analysis is quite helpful in profiling South Africa's service delivery protests covering the period Jan 2004- October 2009. He provides statistical data based on information from Municipal Hotspots Monitor (Municipal IQ 2009b). The data give the following picture:

\begin{tabular}{|cc|}
\hline Year & Number of service delivery protests \\
2004 & 10 \\
2005 & 35 \\
2006 & 2 \\
2007 & 32 \\
2008 & 27 \\
2009 & 83 \\
\hline
\end{tabular}

It is clear that in 2009 the service delivery protests reached unprecedented heights. Alexander (2010:37) therefore describes poor service delivery and lack of accountability protest phenomena as 'a rebellion of the poor'. While tempted to agree with that description I would rather view them as the exercising of the people's rights in the only way open to them for expression of their grievances, dissatisfaction and demands since they were not given an opportunity and a hearing. These protests flowed into the first quarter of 2010. The question is what went wrong in our democratic dispensation? Why are the people not getting services to which they are entitled? Is the promise of 'a better life for all' a smoke screen? Is it indeed an empty slogan meant to keep South Africans hoping against hope? God forbid!

These questions should be causing the government real headache because it needs conditions of peace in order to carry out its mandate. News24.com on 21 October 2009 
reports the words of the Minister of Cooperative Governance and Traditional Affairs Sicelo Shiceka, uttered at a local government Indaba held at Boksburg that there should be no service delivery protests by 2014 . He told the Indaba that he wanted a responsive, efficient and effective and accountable local government. This Indaba was necessitated by violent protests that took place throughout the country. The words of the minister clearly indicate that there is gross unresponsiveness, inefficiency, ineffectiveness and lack of accountability among local government officials and employees. In other words, the minister blames poor service delivery on lack of capacity on the part of local government functionaries; not so much on lack of resources. Of course there is lack of capacity; News24.Com on October 21 2009 reports that assessment carried out in all nine provinces found that there is a vacancy rate of $12 \%$ for senior managers. The minister does also not seem to be aware of the endemic corruption that diverts much needed resources for improvement of service delivery. The problem of lack of sufficient financial resources that disables municipalities to pay their bulk suppliers and that of corrupt officials who abuse state funds meant for service delivery should be addressed; the minister, I believe should have addressed them unequivocally.

Researchers from the Centre for Sociological Research (CSR) list the following findings after an in-depth research in the four areas that they identify as 'service delivery hotspots' namely, Piet Retief, Balfour, Thokoza and Diepsloot (Sinwell et al 2009:1):

- The communities involved in this recent cluster of service delivery protests share many of the same problems and frustrations. Poverty and unemployment levels are high compounded by a lack of basic services including water, sewage systems, street lighting, paved roads as well as adequate and appropriate housing.

- It is clear that the four protests only occurred after unsuccessful attempts by community members to engage with local authorities over issues of failed service delivery.

- The cases of Balfour and Thokoza suggest that the brutal response by police contributed to the violence, rather than the protesters themselves being solely responsible.

- We didn't find any evidence that xenophobia was the prime motivator behind the service delivery protests. While xenophobic attitudes are widespread, these protests have been primarily directed at issues pertaining to local government service delivery.

- Political divisions clearly play an important role in producing frustrations among the masses, particularly in Thokoza where there is an IFP stronghold. In Diepsloot, protests have at least partially emanated from concerns that particular areas of the community are prioritised over others. We found no evidence that people's demands were rooted in a campaign against the Zuma administration or the national policies of the ANC, but rather the failure of the ANC to implement policy at a local level. In fact, the case of Piet Retief revealed that the protestors were in support of the ANC. However, all the communities sampled in this research expressed discontent over what they felt was lack of communication and accountability at various levels of local government.

- The findings presented confirm that the frustrations with government service delivery and protests which result from this will remain part of the South African political landscape as long as people do not have access to basic services and are unable to find effective channels through which to express their demands.

From the abovementioned findings, it seems that the core causes of service delivery protests are the continuing poverty, unemployment, inability of the ANC to implement policy and lack of participation and say by communities in local government structures and systems. Communities are not given an opportunity to express their grievances and demands and are not given a hearing by local government authorities. The police brutality in dealing 
with protests is not helpful either; it instead fuels the frustration and anger of communities leading to violence. Mathekga and Buccus (Undated paper: 12) too, emphasise frustration, poverty and especially the communities' lack of participation in the local government structures and processes. They point to this participation as a necessity for efficient and effective governance and as a constitutional requirement, saying: "The Constitution of South Africa (Act 108 of 1996: Chapter 7) states that it is the object of the local government to "encourage the involvement of communities and community organisations in the matter of local government." Participation would give residents an opportunity to monitor governance and administrative projects and processes of the local government. It would furthermore forge good relationships between the local government and local communities. Nothing can beat good relationships in bringing efficiency and stability. Mathekga and Buccus go on to blame the lack of community involvement and active participation in local government affairs: "The limited role that communities play in the local government system in South Africa since the end of apartheid regime accounts in part for the current stalemate in the system". I agree.

What is said above is reminiscent of Gerald Baraza's (2005-06-23 13:26:05) online comment on Oluwatuyi's 2004 online article (http://www.acton.org/commentary/commentary_227.php). Citing the former United Nations Secretary General, Boutros Boutros Ghali on the causes of conflict, he states: "The deepest causes of conflict are "economic despair, social injustice and political oppression." In the current South African context service delivery that is supposed to open up avenues for 'a better life for all' promised in 1994 and in subsequent election campaigns is deficient. The economic lives of the citizens are therefore not improved, which leads to violent and disruptive protests by residents of various townships.

It seems however, as pointed out by Mathekga and Buccus that lack of citizen involvement and participation in local governance systems as well as lack of structures for dialogue with the government cause more dissatisfaction, frustration and indignation ( $\mathrm{cf}$ Idasa, Local Governance Unit 2010:2). This causes serious distrust by the citizens, of the local government because as (Idasa, LGU 2010:2) points out, "the government's faith in local government as the sphere that is closest to people and the delivery arm of the state is not shared by citizens" with devastating consequences.

\section{Greed and Corruption of Some Employees is Disabling}

Greed and corruption of municipal employees entrusted with resources for service delivery are destabilising and disabling service delivery. One of the most painful stories is one of residents of Paterson in Eastern Cape whose photos were shown on the first page of the Daily Sun of Wednesday $20^{\text {th }}$ January 2010 sharing water with a pig. Reports show that the residential area last had fresh tap water in September 2008. This is so, not because there is no money, but because of greed, corruption and mismanagement. Their story reveals that in 2009 their town received R18 million from the government allocated specifically for water. The woman who spoke to the Daily Sun about this matter told the reporter that the municipality allegedly used R9 million being part of the R18 million water allocation to pay municipal employees' salaries, creditors and general expenses. The question is: what became of the budget for salary payments? Probably fraudulent activities! Otherwise how could the use of money allocated for water be explained? After all this, no one is certain about what happened to the other R9 million. People have once again to hope against hope that the R72 million that the Department of Water Affairs is said to have allocated for the water project would be used accordingly. No guarantee can of course be given. 
Oluwatuyi (2004:2) citing the high rate of capital flight out of, and corruption in Africa as the cause of abject poverty that the continent is known for, suggests that poverty "... is a problem that must be addressed not only by legal measures but also by the inculcation of a culture of personal moral responsibility that recognises the damage done to the common good by corrupt exchanges" (cf Koopman 2008:252). Looking at the extent of corruption in South Africa, one is bound to agree with Oluwatuyi and hope that such inculcation happens sooner than later because corrupt behaviour perpetuates poverty which undoubtedly undermines human dignity and leads to increased criminal activity in our cities, townships, villages and suburbs.

\section{Unemployment}

South Africa has a remarkably high unemployment rate (Kingdon and Knight 2001:1; Klasen and Woolard 2008:2). Kingdon and Knight (2001:1) citing the 2000 statistics, show unemployment hovering around $39 \%$ on the broad definition and $26 \%$ on the narrow definition (for an explanation of 'broad and narrow definition' see Kingdon and Knight 2007:827). Klasen and Woolard (2008:1) also show the unemployment statistics hovering around 30\% between 1993 and 2006 .

Unemployment has recently been highlighted through acts of illegal mining in Barberton and Welkom areas; acts that are life-threatening in the course of which some people have died and will probably continue to die. Poor people are lured to these dangerous activities because of poverty as a result of unemployment. They become pawns in the schemes of ultra rich monsters who never get satisfied. Of such monsters the Bible says in a condemnatory tone: "Your life here on earth has been full of luxury and pleasure. You have made yourselves fat for the day of slaughter. You have condemned and murdered innocent people, and they do not resist you" (James 5:5 and 6). Such ruthless people like the ones who for their own benefit exploit the poor and put their lives in jeopardy deserve such strong condemnation.

It seems the government is heeding such call to condemn illegal mining syndicates. In BuaNews of 17 September 2009, the minister of Mineral Resources Susan Shabangu described illegal mining as "a huge, multi-billion rand criminal industry featuring national and international syndicates and valued at some R5.6 billion." She continued: "These goldsmuggling syndicates are highly organised, dangerous and well-resourced." What is pleasing is that the minister seems intent on taking strong action against illegal mining and has indicated that the newly formed Hawks had been tasked with cracking down illegal mining and syndicates involved in gold smuggling. It is however, not yet clear what progress has been made on this contagious issue.

The need to shake off the shackles of unemployment has quite recently (before the state of the nation address) been strongly expressed by protesting Siyathemba residents who demanded that the local mining company should employ them. The Sowetan, of Tuesday, 09 February 2010 reports that angry residents threatened to throw themselves into the shaft of the Burnstone mine. What would push people to such life-threatening action but the serious need to shake off unemployment and related suffering?

Unfortunately, protests against unemployment often flow over into xenophobic activities. It is reported that angry residents allegedly also set alight shops belonging to foreigners most of whom were Pakistanis. Every time the question of unemployment is raised the presence of foreigners and their booming businesses are immediately seen as the cause of locals' lack of employment and business opportunities resulting in the persecution of foreigners that has already given South Africa an extremely negative image. Sinwell et al 
(2009:3) report about the problem hinted to above: "Some community members felt that the businesses that Pakistani immigrants had opened, which carry a wide range of products are detrimental to the success of local black owned businesses, which can only offer a limited choice of products. One interviewee said, 'In the business sense, Pakistanis must go." A similar sentiment was echoed by an interviewed young man (Sinwell et al 2009:3) who said: "Swazis are a problem; they leave Swaziland for Mpumalanga and take up jobs in key positions of governance." It is obvious that this issue needs urgent resolution. To that end the ANC promised during recent election campaigns to create 500000 job opportunities which further raised hopes and expectations. During the state of the nation address on 11 February 2010 President Zuma mentioned that 480000 job opportunities were created. While the ANC and its Alliance partners applauded Zuma on that achievement, many people from opposition parties and NGO sector echoed their doubts and actually blamed the president of misleading the public indicating that millions of jobs have instead been shed.

The obvious consequence is the continued extreme poverty among black South Africans. Oluwatuyi (2004:1) states the horror of poverty: "Those suffering in extreme poverty lack access to the good things of life and life's fulfilment and expectations are threatened. This undermining of human dignity makes the amelioration of poverty a moral as well as an economic issue." When one observes carefully, black townships are the ones that continue to experience unrest, to be poverty enclaves, to have the largest number of unemployed people who in addition have to struggle for basic needs like housing, water, electricity, sewage and so forth. Recent service delivery protests are evidence of the aforesaid. The question is how long are black South Africans still to wait for the promised 'better life for all?' This question is reminiscent of Boesak's (1984:xii) cry for liberation from the grip of a ruthlessly oppressive white minority regime, strongly articulated by way of citing Psalms 13:2: "How long must I bear pain in my soul, and have sorrow in my heart all the day?" Can South Africans afford to wait any longer? Something needs indeed to be done urgently. All South Africans including the church and civil society organisations should make an exerted effort to address this situation meaningfully. The words of South Africa's former president Nelson Rolihlahla Mandela in his speech to the Trafalgar crowd on $3^{\text {rd }}$ February 2005 highlight the imperative and urgency of meaningful action: “...overcoming poverty is not a gesture of charity. It is an act of justice. It is the protection of a fundamental human right, the right to dignity and a decent life." My focus is briefly on the role of the church; what role could the church play in this regard? As South Africans we know what the church is capable of as evidenced by its tireless active involvement in the struggle against apartheid.

\section{The Role of the Black Church}

Does the black church and theology have a role to play in the situation giving rise to service delivery protests? These service delivery protests, no doubt represent the poor people's struggle for fuller humanity and liberation. Nico Koopman (2008:250-253) outlines the public role of the church in the light of Jesus Christ's three offices namely, the prophetic, the priestly and the royal and suggests that vulnerability should form the basis to such a role. He points out (2008:240): "As witnesses of Jesus Christ, the church has a threefold presence in public life; namely, to be vulnerable prophets, priests, and royals. A vulnerable church is a faithful church, and therefore a relevant church". The implication is clear; the church can only be meaningfully helpful if it identifies with the vulnerable in a prophetic, priestly and kingly presence and action. 


\section{The Imperative of Church Involvement}

Koopman (2008:251-253) elaborates more on this triad of the church's public role. Under the vulnerable prophets' role, he lists five important church commitments, derived from James Gustafson:

i) It is about spelling out a luring, inviting vision of a good society. Such an inviting vision should as Charles Gerkin (1997:143) intimates; revive "an abiding sensitivity to God's presence and conformity to the purposes of divine presence" that can engender required transformation and liberation in the public domain. The prophetic role by the vulnerable black church should give a clear vision of fuller liberation and hope to the suffering majority.

ii) Offering courageous criticism where the status quo does not adhere to that vision. Lack of community participation and corrupt behaviour of government officials, for example should be pointed out without fear and favour. This will help sensitise them to embrace God's justice. Another area needing the church's honest criticism is political leaders' exaggerated self-serving. I believe the situation demands a very serious prophetic word such as the one God instructed Ezekiel to deliver to the shepherds of Israel in Ezekiel 34. In this chapter God instructs Ezekiel to prophesy against the shepherds of Israel. The prophet had to speak damnation to the leaders of the people saying: "Thus saith the Lord God unto the shepherds: 'Woe be to the shepherds of Israel that do feed themselves! Should not the shepherds feed the flocks? Ye eat the fat, and ye clothe you with the wool, ye kill them that are fed: but ye feed not the flock ... but with force and with cruelty have ye ruled them"' (KJV). There are basically two things that the Lord opposes in the conduct of the shepherds of Israel namely, the corruption of self-enrichment at the expense of the flock and their autocratic rule over the people. These two sins refer to economic and political injustices against which God passed judgment.

The church as God's messenger in the world needs to bring God's will to bear in the world - the church has to warn the authorities and government officials against corruption and the protesters against violence.

iii) Telling the narratives of suffering and despair, and of victory and hope. This will only be possible if the church employs Black Theology which has the experience and clear understanding of the victims' suffering and aspirations and the ability to give them hope through comforting words and meaningful actions.

iv) Analysing situations technically, philosophically and in an interdisciplinary way and then suggesting solutions on the basis of such thorough analysis.

v) Prophetic speaking is about participating in policy discourse in society, where decisions have to be taken within the space of political limitations. I believe it should also be about coordinating community participation in governance especially at local level. It should especially be about encouraging the bottom up approach to governance. The bottom line for the church, should as already mentioned, be identification with the vulnerable and their vulnerability in a non-prescriptive, inclusive, interactive participative, serving mode, constructive, people friendly language and with hermeneutic competence (Koopman 2008:251, citing Bernard Lategan).

Under the vulnerable priests' role Koopman borrows Rebecca Chopp's four modes of public theological discourse. The four modes are: 
i) The use of the prognosis of empathy - the ability to identify with and understand someone different than oneself. The church as a vulnerable priest must stand on the side of the poor if it is to be found on the side of God and Jesus of Nazareth as the Kairos Document (1985:9) theologians indicated in the context of the struggle against apartheid. In order to do this effectively the church must according to Boesak (1984:25) have: "the ability to identify with the community it serves..." He further states: "And the church must not be afraid to identify with the struggle of the people."

ii) Solidarity in praxis, which implies the forming of a network of interrelations among multiple and contending discourses... The black church must identify and pledge solidarity with the poor communities.

iii) Transcendence as possibility and praxis, which implies the creation of a public space in which compassion is cultivated as hope; in which slavery, classism, and the denial of the dignity of women have no place; and in which history is transfigured and justice is enacted. The black church has as "an eschatological or ultimate symbol of liberated existence" (Legge 1992:160) to help communities counter current forces that threaten the vision of fuller freedom and hope of poor South Africans who were promised 'a better life for all.' The black church should become the voice of these poor communities. The church has indeed an important role to play.

iv) Chopp's fourth mode entails that the testimonies of the marginalised deserve priority. This should help restore the human dignity of the poor and encourage needed urgency in addressing the plight of the victims of poor service delivery. Legge (1992:162) makes an important contribution in stating the imperative of the church towards the world and the importance thereof for the church when she says: "To participate in the kingdom, then, the church worships God and works for the historical liberation of the whole people of God." Our God is the God of justice and our worship of God should have justice as its greatest mission in reflection of the just God and Father of our Lord Jesus Christ. We need to reflect and disseminate the qualities of Jesus - compassion, kindness, forgiving love, commitment to justice and so forth.

The last of Koopman's (2008:252) church's public role is that of the vulnerable royals. Acting as vulnerable royals entails that, as the church we live with and instil hope and confidence engendered by the resurrection of the crucified Lord Jesus. This task also entails according to Koopman (2008:253) the protection of the vulnerable and marginalised by "being advocates of human rights, rights that resist the violation of dignity, and that help dignity to flourish by championing for values like equality, freedom, justice, and equity." At the centre of this task is proclamation of and living out the gospel of hope and Black Theology seems most suited to this task and to addressing the South African problem of poor service delivery.

\section{Black Theology as the Black Church's Means of Intervention}

One of the important tasks of the black church even today is to continue the task of liberation which can best be achieved through doing Black Theology. Black Theology should have the intention of continuing to morally and materially support the struggles of the black poor. The task of Black Theology is according to Cone (1969:117) "to analyze the black man's condition in the light of God's revelation in Jesus Christ with the purpose of creating 
a new understanding of black dignity among black people, and providing the necessary soul in that people, to destroy white racism." In the present context, it is to resolve poor and lack of service delivery in the non-racial democratic South Africa. The focus in the context of this article is the new reality of lack of and poor service delivery. Black theology as espoused both in the USA and South Africa is ... concerned with the realities of the experience of blacks wherever they live under oppressive situations (cf Storm 2008:1). Maimela (1998:111) sees Black Theology as characterised by the fact that "it arises from the experience of one or other form of human oppression, thus focusing attention on the concrete and particular broken relationships in society."

Maimela (1998) and Storm's (2008) focus on "the concrete and particular broken relationships in society and one or other form of human oppression" and "the experiences of blacks wherever they live under oppressive situations" respectively rather than exclusively on racial oppression, is helpful in reflection on the need for Black Theology to intervene in conditions of poor service delivery as a dehumanising and impoverishing phenomenon. This position frees Black Theology of the indictment that it is not relevant today because it is trapped in an exclusive oppositional mode (Moore page 8). Motlhabi (2008:15) also focuses on the need for Black Theology to practically address contemporary human suffering: "...It had to be addressed by becoming practically involved in the struggle of the here and now and by seeking to make the Christian Gospel relevant and meaningful to this struggle". Yes indeed, Black Theology as 'engaged theology' (Jones) cannot afford to be philosophical about the suffering of the poor. The practical involvement of Black Theology should inspire hope through pointing to the victorious possibilities in Christ in the midst of suffering. Writing about the black church and the black church's liberating message to which Martin Luther King Jr. was committed, as the primary source of his theology and tenacity in the struggle, James Cone (1984:4) says: "Martin King's close ties with the black church in preference over the alternatives indicate that his primary commitment was to that [suffering] community." Black theologians need the kind of commitment to their struggling communities that was evident in Martin Luther King, the prophetic theologians during the struggle against apartheid and many other Christian struggle leaders.

Today there is no longer legislated white racism in South Africa. Though the legacy of racist policies still continues, we have a constitution that is democratic, non racist, non sexist and that includes a bill of human rights. We, however, still face extreme conditions of poverty and lack of basic services. Although the current appalling conditions of poverty that still face black South Africans cannot be compared to the apartheid squalor, the people's conditions have not improved sufficiently for them to enjoy the fruit also of economic liberation. There are still a lot of challenges as shown above that need active practical intervention. Basil Moore (undated research paper, page 3) states about the role of Black Theology in the post-apartheid context: "There are other elements of black experience of oppression and alienation which have to be encompassed by the term 'black'. I think here of the violence which invades the life of every black person, of the squatter camps, of the break down of family life, of the education crisis and so on." Poor service delivery should indeed also form part of the agenda of the post-apartheid Black Theology programme.

\section{The Nature and Contents of the Church's Intervention}

We have pointed out that Black Theology is the black church's instrument for intervention in crises facing black people wherever they live. The black church has in the past employed with success, Black Theology during the struggle against apartheid. The nature of inter- 
vention this time should be a bridge building process aimed at helping communities and local governments to meet in the spirit of mutual respect and understanding. This is achievable as Black Theology is also defined as a 'theology of listening' according to Frank Chikane (as cited by Moore). The strategy to be employed should indeed be different from those that were employed during the struggle against apartheid as we have the most democratic constitution and government in place.

There are in my opinion two things that Black Theology will have to communicate to both local government authorities and residents namely, commitment and cooperation. Firstly, it must be emphasised that the two parties, but especially the local government, need to be committed to inclusive governance. Local government authorities on the one hand need to accept the participation and involvement of residents as non negotiable for good governance. On the other hand, residents must be committed to participate and make meaningful contribution to local governance through attendance of meetings and being whistle blowers in cases of corruption. Residents must be prepared to hold local government authorities accountable. Black Theology should in the case of poor service delivery situation help encourage the adoption of the bottom up approach in the local government system. There is evidence that this participative approach has been disregarded in local government matters in contravention of the constitution as mentioned earlier. This leaves a gap between local government structures and citizen organisations. Such a gap leads to frustration and distrust on the part of residents. Black theologians will in this regard have to encourage and model commitment to corporative governance, cooperation and transparency. The other commitment required of the local government authorities is to dealing effectively with corruption of their officials. This, black theologians will have to communicate unequivocally if we are to make progress in improving service delivery.

\section{Conclusion}

This article has highlighted recent service delivery protests as the poor people's expression of anger and frustration at poor service delivery. The article decries the disablement of delivery on the promise of 'a better life for all' by exclusive governance at local government level, corruption, lack of capacity and mismanagement. The article further suggests that the church or black theologians must intervene with the aid of Black Theology as an instrument that is capable of building bridges between local governments and struggling communities and of instilling hope. The church is called to be faithful by taking up responsibility as vulnerable prophet, vulnerable priest and vulnerable king following Koopman's (2008) insightful extrapolation of the church's public role in society.

\section{BIBLIOGRAPHY}

Alexander, P 2010. Rebellion of the poor: South Africa's service delivery protests - a preliminary analysis. Review of African political economy. 37(123):25-40.

Baraza, G 2005. Online comment on Rev Michael Oluwatuyi's article 'African solution for Africa's poverty. Blessed is he who considers the poor (Ps. 41:1). In The Acton Institute for the study of religion and liberty. http://www.acton.org/commentary/ (Accessed on 2010/03/12).

Boesak, A 1984. Black and Reformed: Apartheid, Liberation and the Calvinist Tradition. Johannesburg: Skotaville Publishers.

Buanews 17 September 2009. Govt Works Hard to Crush Illegal Mining, Syndicates. Cone, J 1969. Black theology \& black. New York: Seabury Press. 
Cone, JH 1984. Martin Luther King Jr., Black Theology - Black Church. Theology Today. Vol 40 (4):1-10. http://theologytoday.ptsem.edu/jan1984/v40-4-article3.htm (Accessed on 2010/03/05).

Daily Sun, Thursday 05 January 2010. 'When R18m is swallowed by greed, you have to find water where you can ... drink with pigs'.

IDASA Local Governance Unit 22 January 2010. The state of local government and service delivery in South Africa: issues, challenges and solutions. Idasa: An African Democracy Institute. Submitted to the portfolio committee on co-operative governance and traditional affairs (COGTA) for public hearings: co-ordinated service delivery

Gerkin, CV 1991. Prophetic pastoral practice: a Christian vision of life together. Nashville: Abingdon Press.

Hough, M. Violent protest at local level in South Africa: revolutionary potential? Director: Institute for Strategic Studies, University of Pretoria. http://ajol.info/index.php/smsajms/article/viewFile/42646/9514 (Accessed on 2010/02/16).

Jones, WR. Assessing Black Theology: toward an interim assessment of Black Theology. Chicken Bones: a journal for literary and artistic African-American themes.

Kairos document 1985. Chapter 5. Challenge to action. God sides with the poor. http://www.-sahistory.org.za/pages/library-resources/official (Accessed on 2010/03/22).

Khumalo, G, Ntlokonkulu, L, \& Rapoo, T. Alternative service delivery arrangements at municipal level in South Africa: assessing the impact of electricity service delivery and customer satisfaction in Johannesburg. Research Report 100. http://www.cps.org.za (Accessed on 2010/02/12).

Kingdon, GG, \& Knight, J 2001. Unemployment in South Africa: the nature of the beast. ScienceDirect - World Development, 2004 - Elsevier. Available online 23 January 2004. http://www.sciencedirect.com/science? (Accessed on 2010/07/27).

Kingdom, G, \& Knight, J 2007. Unemployment in South Africa, 1995-2003: Causes, Problems and Policies. Journal of African Economies 16(5):813-848. http://jae.oxfordjournals.-org/cgi/reprint/16/5/813. Downloaded from http://jae.oxfordjournals.org at Unisa on August 5, 2010.

Klasen, S, \& Woolard, I 2008. Surviving unemployment without state support: unemployment and household formation in South Africa. Journal of African Economics 18(1):1-51. Downloaded from http://jae.oxfordjournals.org at University of South Africa on August 5, 2010.

Koopman, N 2008. Vulnerable church in a vulnerable world? Towards an ecclesiology of vulnerability. Journal of Theology 2(2008):240-254.

Legge, MJ 1992. Part III. The church in solidarity: liberation ecclesiology. https://tspace.library.utoronto.ca/bitstream/1807/.../4/Legge_Solidarity.pdf. Accessed on 2010/03/03.

LenkaBula, P 2005. Justice and reconciliation in post-apartheid South Africa: a South African woman's perspective. International Review of Mission 94(372):103-116.

Mail and Guardian Online July 20 2009. Service-delivery protests a ‘warning sign' for govt. http://www.mg.co.za/section/national Accessed 2010/07/24.

Mail and Guardian July, 26 2009. A nation united in protest. http://www.mg.co.za/section/national Accessed 2010/07/24. 
Maimela, S 1998. Black Theology. In Maimela S and König (eds.) Initiation into theology: the rich variety of theology and hermeneutics. Pretoria: JL van Schaik Publishers: 111-119.

Mandela, NR 2005. Speech in London on $3^{\text {rd }}$ February 2005 during the campaign to make poverty history. www.makepovertyhistory.org/docs/mandelaspeech.doc Acessed on 2010/08/06.

Mathekga, R, \& Buccus, I. The challenge of local government structures in South Africa: securing community participation. Critical Dialogue-Public Participation in Review. Centre for Public Participation. http://www.idasa.org.za/ (Accessed on 2010/02/16).

Moore, B. Black Theology revisited. Undated Research paper.

Motlhabi, M 2008. African theology/Black Theology in South Africa: looking back, moving on. Pretoria: University of South Africa.

News24.Com 2009 October 21. 'No service delivery protests by 2014'.

News24.Com 2009 October 21. 64 municipalities in dire straits.

Oluwatuyi, M 2004. An African solution for Africa's poverty. Blessed is he who considers the poor (Ps. 41:1). The Acton Institute for the study of religion and liberty. www.acton.org/commentary/commentary_227.php. Accessed on 2010/03/12.

Sexwale takes aim at housing corruption. http://www.theherald.co.za/PrintArticle 2009/11/02 (Accessed on 2010/08/26).

Sinwell, L, Kirshner, J, Khumalo, K, \& Manda, O 2009. Service delivery protests: findings from quick response research on four 'hot spots' - Piet Retief, Balfour, Thokoza, Diepsloot. Centre for Sociological Research, Faculty of Humanities, University of Johannesburg, with support from Rosa Luxemburg Foundation.

http://www.uj.ac.za/Portals/159/docs/CSR (Accessed on 2010/02/16).

Sowetan 09 February 2010. Residents demand mine jobs.

Storms, S 2008. 'Black Theology. Enjoying God Ministries: biblical \& theological resources of Dr Sam Storms'. Series: Historical Theology. 